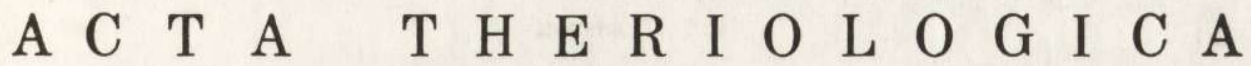

VOL. 19, 2: 19-25.

BIAŁOWIEŹA

May, 1974

Lennart H A N S S O N

\section{Influence Area of Trap Stations as a Function of Number of Small Mammals Exposed Per Trap}

[With 2 Tables \& 3 Figs.]

\begin{abstract}
A mathematical model was developed for the distribution of captures in trap lines with variable distance between trap stations. A constant width of influence was assumed all along the line, whereby a linear regression was obtained between catches and distances to neighbouring trap stations. Ranges and density could be computed from the equations. It was, however, in most field sampling impossible to obtain a significant regression and catches did not vary either with distance or time. These conditions are interpreted as due to variable areas of influence caused by variations in numbers of approaching animals per trap. Similar conditions seem to apply to all trap lines run in gradients of trap or animal densities.
\end{abstract}

\section{INTRODUCTION}

Recent attempts to evaluate density of small mammals have included the use of assessment lines, applied after removal catches ( $\mathrm{Smith}$ et al., 1971; Ryszkowski et al., 1971). Such lines operate along a gradient of changing numbers of animals, i.e. the number exposed per trap varies. The method is based on the assumption that the catch is directly proportional to the number of animals exposed per station. This assumption was also the basis for following attempt to develop a new method for density estimation, which failed, however. The intention was to evaluate numbers and ranges at the same time so densities could be calculated at once.

\section{METHODS}

Trap stations were placed with variable distance from each other on trap lines (Fig. 1). The "effective" distance, $d_{i}(i=1,2,3, \ldots \ldots n-1)$, is the sum of half the distances to neighbouring stations. Let $r$ be the 
distance from which the animals are removed at a certain lapse of time. $L_{n}$ is the total length of the trap line and $l$ the width of the trap stations. $C_{i}(i=1,2,3, \ldots \ldots \ldots)$ is the catch in the various trap stations, the number of which is $n$ in each of $N$ lines.

With direct proportionality between catch and number of animals exposed, i.e. with a constant distance of influence of the trap lines the density $(D)$ is:

$$
D=C_{i} /(2 r+1) d_{i}
$$

However, the catch may also be expressed as

$$
C_{i}=(2 r+1) d_{i} D(+E)
$$

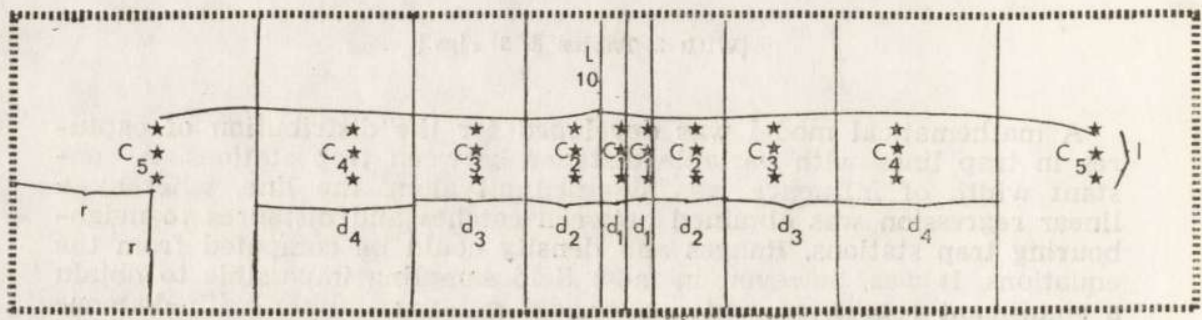

Fig. 1. Trap line with variable distance between trap stations. Influence areas, at a constant distance of influence, are indicated. $C_{1}-C_{5}=$ trap stations catches, each station with a width of $1 \mathrm{~m}, d_{1}-d_{5}=$ the sum of half the distance to neighbouring stations. $L_{10}=$ the lenght of a line with a total of 10 stations, $r=$ the assumed constant distance of influence.

Here $E$ denotes animals which possibly reach a trap station from the side of the line, i.e. from the rectangles of influence of other trap stations. When the $C_{i}$ values of one or more trap lines are plotted against corresponding $d_{i}$ values a straight line should be obtained. From (2) the slope $(b)$ of the line is

$$
b=D(2 r+l)
$$

But

$$
D=\sum_{1}^{N} \sum_{1}^{n} C_{i} / N\left(L_{n}+2 r,(2 r+l)\right.
$$

When inserting $D$ in (4) into (3) we obtain

$$
b=\sum_{1}^{N} \sum_{1}^{n} C_{i} / N\left(L_{n}+2 r\right)
$$

From equations $(1-5)$ it is possible to derive estimates of $D$ and $r$. 
In order to obtain a straight line relationship the distances between trap stations in the ends of the trap lines must be less than double the removal distance $\left(d_{n-1}<2 r\right)$. Thus if there is reason to believe that catches in the distant end stations will cause too low a value of the slope of the regression line (b), these end stations should be excluded when a significantly greater slope is obtained with fewer stations. A corresponding change must be made in equation (4) to:

$$
D=\sum_{1}^{N} \sum_{1}^{n-a} C_{i} / N\left(L_{n-a}+2 r\right)(2 r+l)
$$

where $a$ is the number of trap stations, which must be excluded.

Thus

$$
b=\sum_{i}^{N} \sum_{1}^{n-a} C_{i} / N\left(L_{n-a}+2 r\right)
$$

Field sampling was performed with this method around the Stensoffa Ecological Station in South Sweden. The distances between trap stations were $0,5,10,20$, and $30 \mathrm{~m}$. There were 3 or 5 traps per station and the width of the trap stations were 2 or $4 \mathrm{~m}$. The stations were mainly rows but in some cases circles with a diameter of $4 \mathrm{~m}$.

\section{RESULTS}

The regressions obtained with various numbers of lines (Fig. 2, Table 1), were mostly not significantly different from a straight line running parallel to the $x$-axis. The $y$-axis was not intercepted in the origo but consistently on the positive side, indicating an influx of animals from along the side of the trap line. The equations for obtaining ranges and densities were unsolvable or gave rather improbable estimates. Only estimates of Clethrionomys glareolus ( $\mathrm{S} \mathrm{chreber}, 1780)$ in October 1968 and of Sorex araneus, Linne u s, 1758, in September 1972 were in agreement with present ideas of ranges and densities in small mammals. For Apodemus flavicollis ( $\mathrm{Mel} \mathrm{ch}$ ior, 1834) and Microtus agrestis ( $\mathrm{L}$ in ne us, 1761) at least the ranges were unreasonable; the reinfluence rather rapidly and the outermost later on. However, there sults being unrelated to the numbers of lines or animals examined.

If there had been a constant distance from which the animals were drawn, the innermost trap stations should have emptied their areas of influence rather rapidly and the outermost later on. However, there 


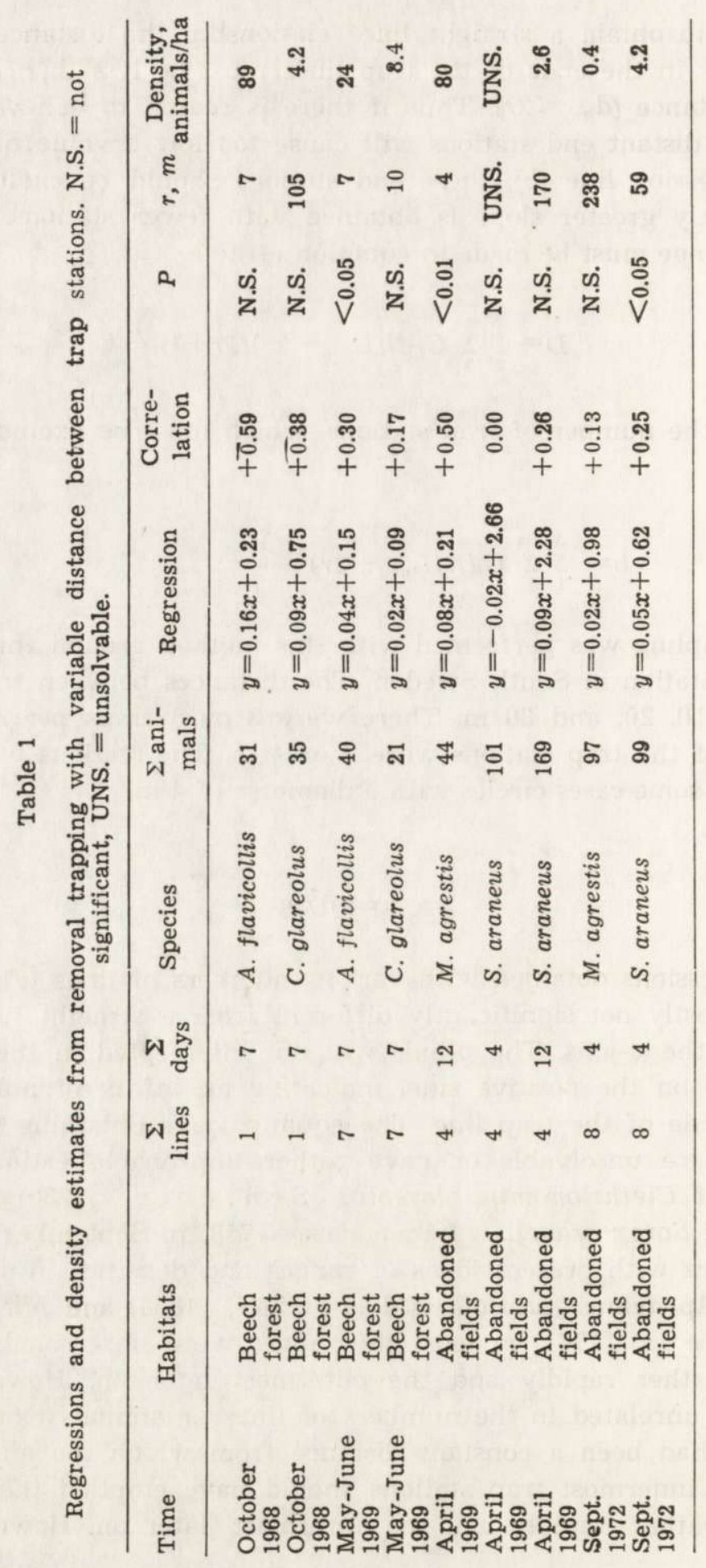


Table 2

Mean day of capture in the various stations on lines with variable distance between stations.

\begin{tabular}{|c|c|c|c|c|c|c|c|c|}
\hline \multirow{2}{*}{ Time } & \multirow{2}{*}{ Species } & \multirow{2}{*}{$\underset{\text { days }}{\Sigma}$} & \multicolumn{6}{|c|}{ Mean day of capture } \\
\hline & & & $C_{1}$ & $\mathrm{C}_{2}$ & $\mathrm{C}_{3}$ & $C_{4}$ & $\mathrm{C}_{5}$ & $\Sigma$ \\
\hline April, 1969 & S. araneus & 4 & 1.8 & 1.4 & 1.4 & 1.8 & 1.8 & 1.7 \\
\hline April, 1969 & S. araneus & 12 & 3.6 & 4.8 & 2.8 & 3.9 & 3.5 & 3.7 \\
\hline Sept., 1972 & M. agrestis & 4 & 1.0 & 1.2 & 1.3 & 0.7 & 1.5 & 1.1 \\
\hline Sept., 1972 & S. araneus & 4 & 1.2 & 0.8 & 0.7 & 1.2 & 1.1 & 1.0 \\
\hline
\end{tabular}

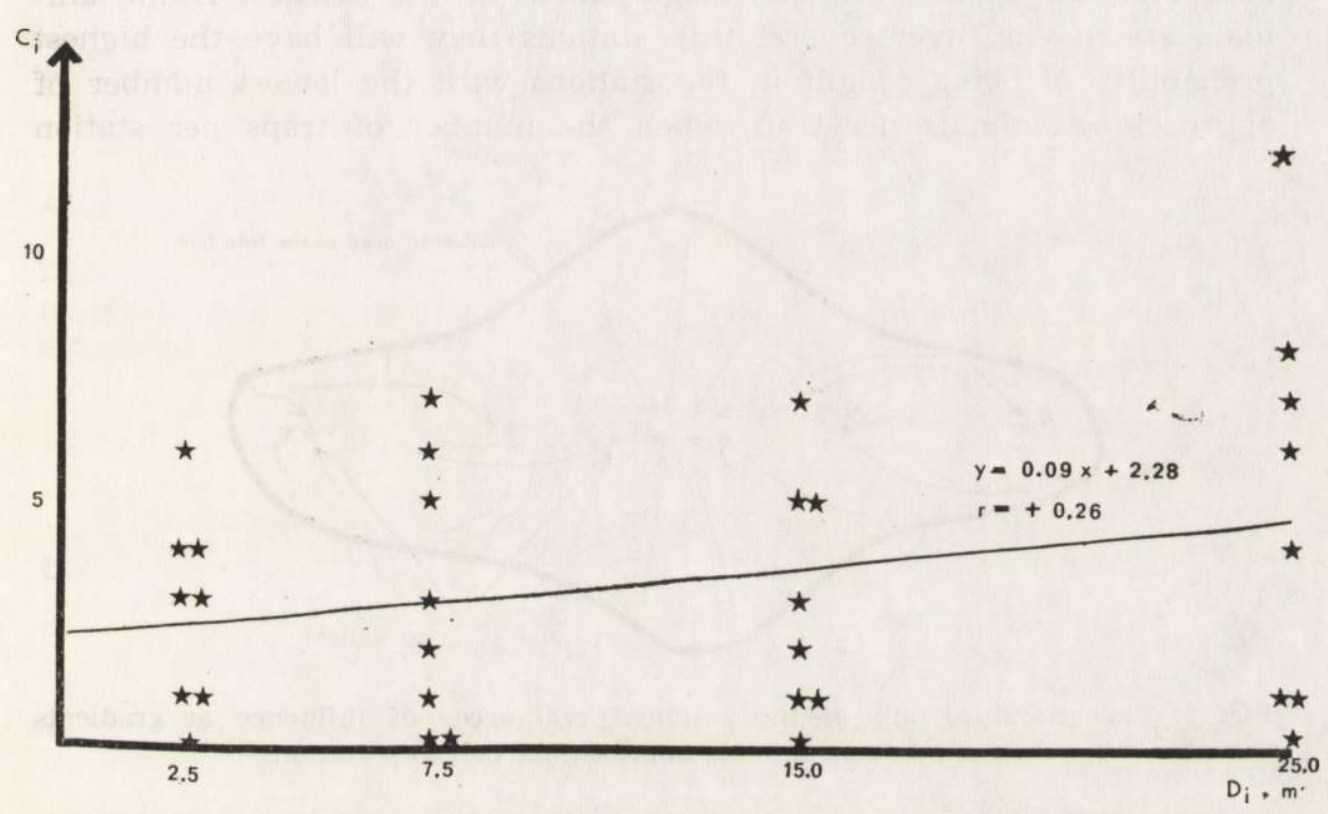

Fig. 2. Regression between the catch in various trap stations $\left(C_{i}\right)$ and the sum of half the distance to neighbouring stations $\left(d_{i}\right)$. Sorex araneus on abandoned fields in April 1969.

were no differences in the mean day of capture $\left(E_{1, k}(C)\right.$ according to $\mathrm{J}$ a $\mathrm{n}$ i on et al. 1968) for the various trap stations (Table 2).

\section{DISCUSSION}

One assumption behind the method suggested is that the trap stations graduallly empty a larger area, constantly increasing in width from the trap line. If wide-ranging animals are caught first and thereafter less mobile animals living close to the lines, false density estimates are ob- 
tained with a low number of removal days. This may be one contributory reason why the method failed.

However, even with this distribution of captures significant regressions through origo should have been obtained, if a constant width had been sampled by the trap stations. The insignificant changes in capture per station both with distance and time showed that there must have been a pronounced inflow to the central trap stations, probably in the way suggested in Fig. 3. Hanss on $(1971$ : 119) also found that the capture distribution did not reflect the movement patterns of the animals and found and sinward " displacement of the catches. If the animals are moving over several trap stations they will have the highest probability of being caught in the stations with the lowest number of approaching animais per trap, when the number of traps per station

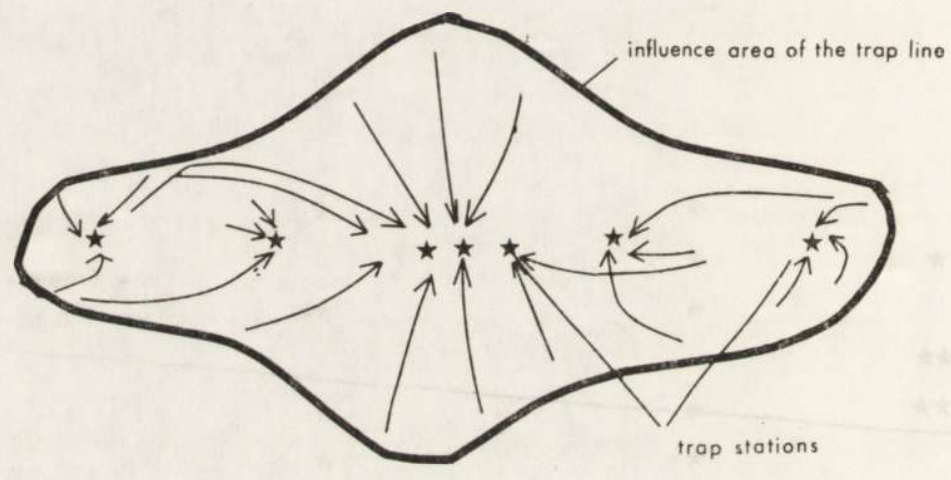

Fig. 3. Theoretical picture of the assumed real areas of influence at gradients in number of animals approaching per trap station.

is limited. According to Andrzejewski et al. (1966) the number of traps per station is very often limited in relation to the number of animals approaching.

In the present case there was a change in the number of animals exposed per trap, caused by a gradient in trap density in an, overall, uniform animal density. With assessment lines the change is similar, resulting from the opposite relation, i.e. constant density of traps in gradients of animal density. A similar effect on captures may appear, resulting in over-estimates of the density in removal areas evaluated by assement lines.

Acknowledgements: I am very grateful to Professor Per Brinck, Zoological Institute, Lund, Sweden, for working facilities at the Stensoffa Ecological Station. The work was supported by grants from the Swedish Natural Science Research Council. 


\section{REFERENCES}

1. Andrzejewski R., Bujalska G., Ryszkowski L. \& Usty$\mathrm{niuk}$ J., 1966: On a relation between the number of traps in a point of catch and trappability of small rodents. Acta theriol. 11: 343-350.

2. Hansson L., 1971: Estimates of the productivity of small mammals in a South Swedish spruce plantation. Ann. Zool. Fennici 8: 118-126.

3. Janion M., Ryszkowski L. \& Wierzbowska T., 1968: Estimate of number of rodents with variable probability of capture. Acta theriol. 13 . 285-294.

4. Ryszkowski L., Gentry J. B. \& Smith M. H. 1971: Proposals to test the density estimation techniques for small mammals living in temperate forests. Small Mammal Newsl. 5: 40-53.

5. Smith M. H., Blessing R., Chelton J. G., Gentry J .B., Golie y F. B. \& McGinnis J. T., 1971: Determining density for small mammal populations using a grid and assessment lines. Acta theriol. 16: 105-125.

Accepted, October 22, 1973.

Department of Vertebrate Ecology,

Institute of Forest Zoology,

Skogshögskolan, Stockholm.

Lennart HANSSON

STREFA DZIAEANIA LINII PUŁAPEK JAKO FUNKCJA ILOSCI MAEYCH SSAKÓW PRZYPADAJĄCYCH NA PU£APKE

Streszczenie

Opracowano matematyczny model rozkładu odłowów na linii pułapek ze zmienną odległością między pułpakami (Ryc. 1). Założono, że działanie takiej linii zależy tylko od odległości między kolejnymi pułapkami. Uzyskane równania regresji pozwalają obliczyć areały i zagęszczenie. Jednakże w warunkach terenowych nie było możliwe otrzymanie istotnych zależności a złowienia nie zmieniały się ani $\mathrm{z}$ odległością ani z czasem (Ryc. 2, Tabele 1,2). Rezultat ten tłumaczy się zmianą strefy oddziałania powodowanej przez zmiany liczby zwierząt zbliżających się do pułapki (Ryc. 3). Wydaje się, że podobne warunki panują na wszystkich tych powierzchniach odłownych na których zmienia się zarówno zagęszczenie zwierząt jak i ilość pułapek. 